\title{
The role of archaeophytes and neophytes in the Dutch coastal dunes
}

\author{
Eduard J. Weeda
}

Received: 7 August 2009 / Accepted: 9 November 2009/Published online: 2 December 2009

(C) The Author(s) 2009. This article is published with open access at Springerlink.com

\begin{abstract}
The position of alien plant species in the Dutch coastal dune vegetation is evaluated considering 12 archaeophytes and 20 neophytes (including one moss), all of widespread occurrence in the coastal area of the Netherlands. Almost all archaeophytes have become part of natural vegetation types. Open scrub communities, in particular Hippophae rhamnoides-Sambucus nigra scrub at the leeside of the outer dunes, and calciphilous mossdominated pioneer vegetation are relatively rich in archaeophytes. Among neophyte vascular species a contrast is apparent between herbaceous and woody species. The majority of herbaceous neophytes are characteristic of man-disturbed habitats and are only infrequently observed in natural vegetation types. However, woody species (as well as the moss Campylopus introflexus) have entered into natural vegetation on a large scale and behave in an invasive way.
\end{abstract}

Keywords Archaeophytes - Dune scrub vegetation . Hippophae-Sambucus scrub · Invasive species · Neophytes . Woody neophytes

\section{Potential habitats for alien species in coastal dunes}

In comparison with inland habitats the coastal dunes are characterized by hard, salt-loaded wind and by supply and movement of sand. The wind governs relief formation and change, as well as causing a high share of sunshine and keeping establishment of tall shrubs and trees in check.

E. J. Weeda $(\bowtie)$

Alterra Wageningen UR,

P.O. Box 47, 6700 AA Wageningen, The Netherlands

e-mail: ejweeda@hotmail.com
Thus lime-rich habitats may preserve an open and sunny character, at least mosaic-wise, without direct human interference. Varying amounts of shell grit and organic debris, together with animal activities, are reflected by considerable local variations in $\mathrm{pH}$ and trophic status.

On a local scale eutrophic conditions may arise from decomposition of remains of marine plants and animals blown into the outer parts of the dunes. A major concentration of eutrophic habitat is found at the leeside of the outer dune-ridge, a belt often dominated by the nitrophilous shrub Sambucus nigra (names of vascular plant species after Stace 1997 or, if not mentioned there, after Van der Meijden 2005). The lower dune pioneer shrub Hippophae rhamnoides, which covers large areas of calcareous dunes, enriches the soil with nitrogen fixed in its root nodules (Zoon 1995). Together with other plants with juicy or fleshy, vitamin-rich fruits-notably Crataegus monogyna and Rubus caesius-Hippophae and Sambucus attract large numbers of migrating song-birds following the coast-line. They drop their excrements in the scrub, making the occurrence of a eutraphent vegetation a self-enforcing process to a certain extent. As Hippophae and Sambucus generally do not build up a continuous canopy (average cover c. $75 \%$ ) a luxuriant herb layer is able to develop under and between the shrubs, even in summer (data from Dutch Vegetation Survey and personal observations).

In a dynamic landscape like the coastal dunes succession from herbaceous to woody vegetation is frequently inverted by deflation or by burial under sand, nutrients becoming available from mineralization of death vegetation remains. This may also give rise to relatively eutrophic conditions, which find expression in abundant development of e.g. Ligustrum vulgare, Urtica dioica, Rubus caesius and Galium mollugo (Doing 1988, 1991: 'Rubus caesiuslandscape'). 
Because of the supply of open, eutrophic habitats the coastal dunes may be expected to offer favorable conditions for the establishment of alien species (Lohmeyer and Sukopp 1992). This paper deals with on the question to which extent this is true, and how many of these alien species must be qualified as invasive.

\section{Archaeophytes in coastal dune vegetation}

When the present chain of Dutch coastal dunes arose after 1000 A.D. (Zagwijn 1986; Doing 1988, 1991), a vast spectrum of species was available to colonize them. Dune vegetation may be termed a 'magnificent rearrangement of plant species' (Weeda 2004). In addition to coastal and riverine (Rhine system) species originally native to Western Europe, many companions of human culture were involved. As far as they have arrived before 1500 A.D., they are labeled archaeophytes. As such Anthriscus cancalis, Aristolochia clematitis and Cynoglossum officinale are mentioned by Lohmeyer and Sukopp (1992), whose area of survey is Central Europe in a broad sense, including The Netherlands. Arctium pubens (part of Arctium minus agg.; Duistermaat 1996), Asparagus officinalis, Bryonia dioica, Carduus nutans and Picris hieracioides are quoted by these authors as anciently naturalized species whose natural area is not known with certainty. In addition, Anagallis arvensis subsp arvensis, Anchusa arvensis, Diplotaxis tenuifolia and Nepeta cataria may be mentioned. Medieval occurrence of Cynoglossum officinale and Anchusa arvensis in the Dutch dunes has been ascertained by palynological research (Zagwijn 1984). Investigation of macroremains has revealed the presence of Anthriscus caucalis, Arctium minus agg. and Nepeta cataria in the Dutch coastal area since Roman times, while Diplotaxis tenuifolia is documented in medieval sites (archaeobotanical database RADAR; Van Haaster and Brinkkemper 1995).

Among natural types of dune vegetation HippophaeSambucus scrub is especially rich in archaeophytes, i.a. Anthriscus caucalis, Arctium minus, Carduus nutans, Nepeta cataria, Asparagus officinalis, Bryonia dioica, Cynoglossum officinale and Picris hieracioides (Lohmeyer and Sukopp 1992), the latter four species also occurring in other types of dune scrub vegetation. Moss vegetation dominated by Syntrichia ruralis var. ruraliformis (moss names after Smith 2004) may contain Cynoglossum officinale, Anagallis arvensis and Anchusa arvensis, the latter two notably on heaps of rabbit droppings. Picris hieracioides is a characteristic species of dune grasslands, together with its specific parasite Orobanche picridis, which can only have settled after its host had established itself.

A somewhat special case is offered by Aristolochia clematitis, an old medicinal herb of Mediterranean origin only exceptionally fruiting in The Netherlands, which has established itself by vegetative means in woodland fringes in the inner dunes. Although its far creeping rhizomes would seem to enable this species to behave in an invasive way, yet its larger stands are of scattered occurrence and rather constant size.

Though all archaeophytes summarized in this paragraph may benefit from human habitat disturbance, with the exception of Diplotaxis tenuifolia none of them is dependent on man-disturbed sites in coastal dune areas. This at variance with their behavior in inland regions, where most of them are neatly confined to arable land (Anagallis arvensis, Anchusa arvensis), ruderal habitats (Anthriscus caucalis, Cynoglossum officinale, Nepeta cataria) or at least habitats with a strong connection to man-built infrastructure (Aristolochia clematitis, Carduus nutans, Picris hieracioides).

\section{Neophytes in coastal dune vegetation}

Neophytes arrived after 1500 , i.e. after the formation of the present coastal dune area. So they met with a more or less established dune vegetation. Table 1 gives a survey of twenty successful dune neophytes. Four selection criteria were used. They should form part of specific dune vegetation. Their new-built area within the dunes should be at least $50 \mathrm{~km}$ long. It should lie at least $500 \mathrm{~km}$ apart from the original area, which implies that species which have reached the Dutch dunes in more or less recent time by continuous area extension (e.g. Catapodium marinum, Oenanthe crocata and Bryum canariense) are excluded. Finally trees were not taken into consideration, because their long life-span makes it difficult to ascertain their degree of naturalization. Some of the twenty selected species are (almost) specific dune inhabitants in the Netherlands, whereas others occur throughout large parts of the country. They partly inhabit similar habitats within the dunes as the archaeophytes, and there is a clear ecological resemblance between some pairs of species (Claytonia perfoliata and Anthriscus caucalis, Chenopodium foliosum and Anchusa arvensis).

More than half of the dune neophytes are monocarp herbs with a short life-span, mostly less than two years. Three of these (Oenothera biennis, O. oakesiana and Corispermum leptopterum) appear to be involved in a process of speciation in their newly acquired area (Wittig et al. 1999; Tokhtari and Wittig 2001). Oenothera oakesiana $(=O$. parviflora var. ammophila $)$ is the only monocarpic neophyte that is largely confined to natural dune vegetation, viz. between Ammophila arenaria and especially Festuca arenaria in the outer dunes. Claytonia perfoliata too has its main point within the dunes in a natural vegetation type, 


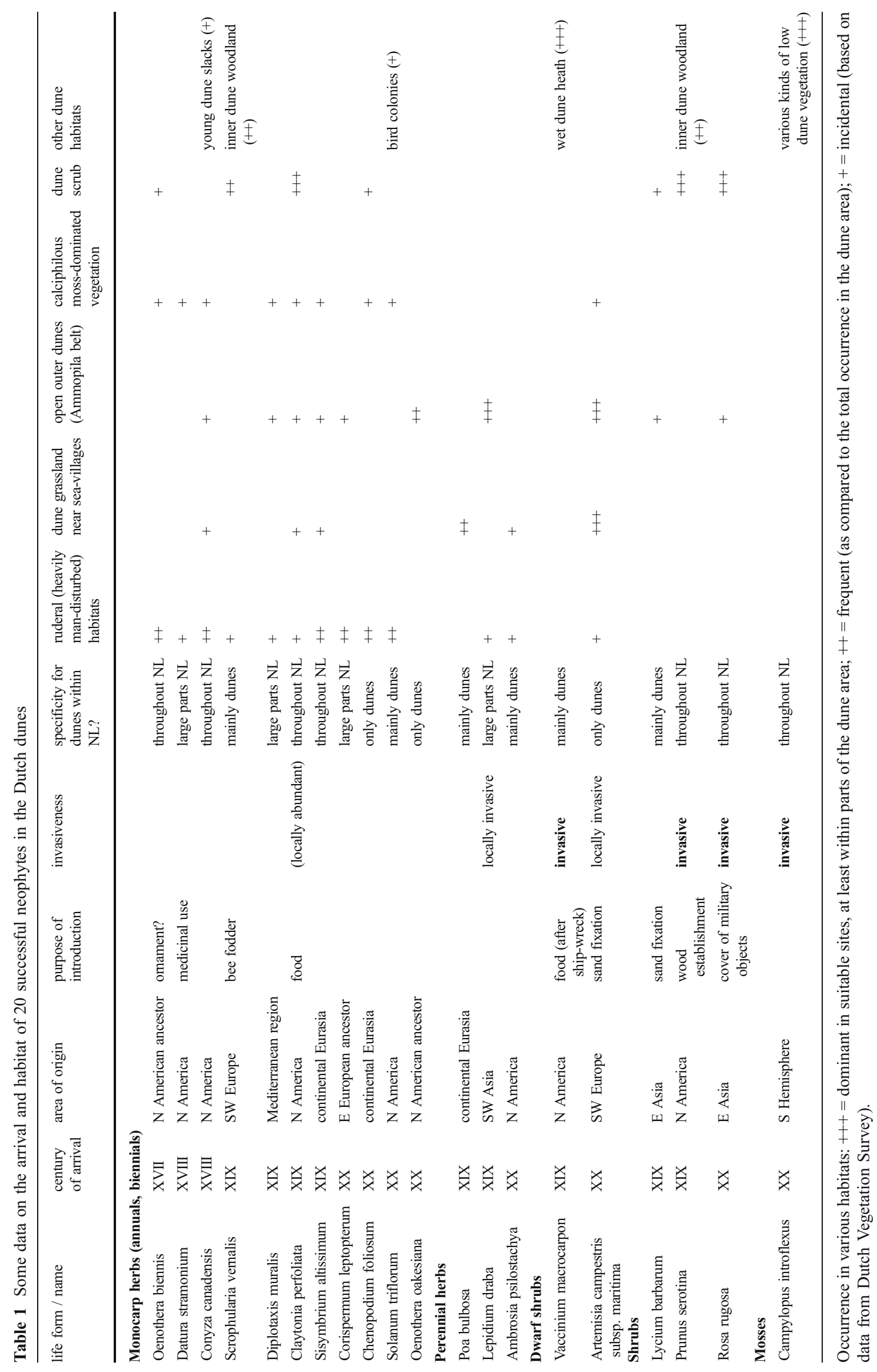


viz. in Hippophae-Sambucus scrub, where it may dominate the herb layer in spring. The other monocarps have their main point in ruderal habitats and enter into natural dune vegetation only to a modest extent, mainly in open pioneer communities, only Scrophularia vernalis preferring woody vegetation. None of the monocarps can be qualified as invasive.

Among the perennial herbs and dwarf shrubs three species are found in dry dune grassland and related mossdominated communities: Poa bulbosa, Artemisia campestris subsp. maritima $(=A$. lloydii $)$ and - to a lesser extentAmbrosia psilostachya. These three species concentrate in sea villages and their surroundings, where dune grasslands are trodden and eutrophicated by man. The dwarf shrub Artemisia campestris subsp. maritima, which was introduced from western France on behalf of dune fixation, can hold a dominant position at the transition of Ammophila dominated vegetation to dune grassland. However, such sites were hardly observed in parts of the dunes remote from human settlements. A still clearer preference for disturbed sites is shown by Lepidium draba, behaving locally as an invasive species in the outer dunes after deposition of foreign material.

Really invasive species are three woody vascular plants-Vaccinium macrocarpon, Rosa rugosa and Prunus serotina-as well as the moss Campylopus introflexus. They all enter natural dune vegetation on a large scale. The latter three species are classified among the 'Top Hundred' of invasive organisms in Europe (DAISIE 2009). The creeping dwarf shrub Vaccinium macrocarpon was taken into cultivation on the Wadden Isles after having reached the island of Terschelling by ship-wreck. It is the only of the species under consideration that is virtually absent from the mainland coastal dunes. Nowadays it plays a large part in wet dune heathland of the Wadden Isles, but most of these heaths have developed after the arrival of Vaccinium macrocarpon, which was therefore involved in their formation from the beginning. Moreover wet dune heath is a species-poor community anyway, apart from the competitive capacities of its constituents (Barendregt 1982). Rosa rugosa was used to hide bunkers in the second world-war and subsequently for ornament and sandfixation. It spreads both by rhizomes and by fruits and is a most difficult invader to combat. The shrub Prunus serotina, introduced into The Netherlands for soil improvement in wood plantations, and the moss Campylopus introflexus are the other major problematic neophytes (Van der Meulen et al. 1987; Ehrenburg et al. 2008). Outside the dunes both are wide-spread on the lime-less sandy soils in the interior. Their recent spread in the dunes is connected with dune fixation. It might counteracted by overblowing with fresh calcareous sand from the outer dunes, i.e. by restoring natural dynamics.

\section{Conclusions}

Most archaeophytes that are widespread in the Dutch coastal dunes have become part of natural vegetation types. Notably outer dune scrub dominated by Hippophae rhamnoides and Sambucus nigra proves a suitable habitat for a number of these species. More than half of the widespread neophytes, on the other hand, have their main point in man-disturbed habitats and only incidentally enter into more natural vegetation. Most of these species have a short life-span.

However, among vascular plant species a striking difference is apparent between herbaceous and woody plant species. Of the herbaceous neophytes only Lepidium draba shows invasive behavior, which is moreover limited to ruderal sites in the outer dunes. The only non-woody plant species that has invaded the Dutch coastal dunes on a large scale is a moss, Campylopus introflexus.

On the contrary, four out of five neophyte shrubs behave as invaders in the Dutch coastal dunes. They have been introduced with the expectation of some kind of benefit: the food-plant Vaccinium macrocarpon, the sand-fixating Artemisia campestris subsp. maritima, the ornamental Rosa rugosa and the 'woodland-preparing' Prunus serotina. Notably the latter two are considered major threats to biological diversity in the dunes at present. In view of the huge and unforeseen problems caused by Prunus serotina (Ehrenburg et al. 2008) it might be considered to terminate planting alien woody plant species in or near the dunes.

Open Access This article is distributed under the terms of the Creative Commons Attribution Noncommercial License which permits any noncommercial use, distribution, and reproduction in any medium, provided the original author(s) and source are credited.

\section{References}

Barendregt A (1982) The coastal heathland vegetation of the Netherlands and notes on inland Empetrum heathlands. Phytocoenologia 10:425-462

DAISIE (2009). 100 of the Worst. www.europe-aliens.org

Doing H (1988) Landschapsoecologie van de Nederlandse Kust. Een landschapskartering op vegetatiekundige grondslag. Stichting Duinbehoud/Stichting Publikatiefonds Duinen, Leiden

Doing H (1991) Landscape ecology of the Dutch coast. European Union for Coastal Conservation, Leiden

Duistermaat H (1996) Monograph of Arctium L. (Asteraceae). Generic delimitation (including Cousinia Cass. p.p.), revision of the species, pollen morphology, and hybrids. Ph.D. Thesis Rijksuniversiteit Leiden

Ehrenburg A, Van der Hagen HJM, Terlouw L (2008) Amerikaanse vogelkers als invasieve soort in de kustduinen. De Levende Natuur 109:240-245

Lohmeyer W, Sukopp H (1992) Agriophyten in der Vegetation Mitteleuropas. Schriftenreihe für Vegetationskunde 25 
Smith AJE (2004) The moss flora of Britain and Ireland. Second edition. Cambridge University Press

Stace C (1997) New flora of the British Isles. Second edition. Cambridge University Press

Tokhtari VK, Wittig R (2001) Evolution and development of plant populations in technogenous ecotopes. Soil Science 1:97-105

Van der Meijden R (2005) Heukels' flora van Nederland, 23rd edn. Wolters-Noordhoff, Groningen

Van der Meulen F, Van der Hagen H, Kruijsen B (1987) Campylopus introflexus. Invasion of a moss in Dutch coastal dunes. Proc $\mathrm{K}$ Ned Akad van Wet C 90:73-80

Van Haaster H, Brinkkemper O (1995) RADAR, a relational archaeobotanical database for advanced research. Veg Hist Archaeobot 4:117-125
Weeda EJ (2004) De duinvegetatie, een grandioze herschikking van plantensoorten. Stratiotes 28/29:45-52

Wittig R, Lenker K-H, Tokhtar V (1999) Zur Soziologie von Arten der Gattung Oenothera L. im Rheintal von Arnheim (NL) bis Mulhouse (F). Tuexenia 19:447-467

Zagwijn WH (1984) Pollenanalytische Untersuchung einer mittelalterlichen Ablagerung in den Küstendünen westlich von Haarlem, Niederlande. Dissertationes Botanicae 72 (Festschrift Welten): $358-384$

Zagwijn WH (1986) Nederland in het Holoceen. Geologie van Nederland, Deel 1. Rijks Geologische Dienst, Haarlem

Zoon FC (1995) Biotic and abiotic soil factors in the succession of sea buckthorn, Hippophaë rhamnoides L. in coastal sand dunes. Ph. D. Thesis Landbouwuniversiteit Wageningen 